\title{
SOURCES OF BEACH SAND AT CRECIENTE ISLAND, BAJA CALIFORNIA SUR, MEXICO: FOURIER GRAIN-SHAPE ANALYSIS
}

\section{FUENTES DE ABASTECIMIENTO DE ARENA DE PLAYA EN ISLA CRECIENTE, BAJA CALIFORNIA SUR, MEXICO: ANALISIS DE FOURIER PARA FORMA DE GRANO}

\author{
Janette M. Murillo \\ Robert H. Osborne \\ Donn S. Gorsline \\ Department of Geological Sciences \\ University of Southern California \\ Los Angeles, Ca. 90089-0740, USA
}

Recibido en enero de 1994; aceptado en mayo de 1994

\begin{abstract}
Fourier grain-shape analysis (FGSA) of detrital quartz grain was used to identify local sources for medium-grained $(0.25$ to $0.50 \mathrm{~mm})$ sand in Creciente barrier island, which is located on the west coast of Baja California Sur, Mexico. A total of 52 samples from Creciente Island and vicinity were analyzed. The results of FGSA include mean values of harmonic amplitude values, which may be employed to characterize the shape composition for each sample. These values were used as for statistical procedures used to identify sand sources. Factor analysis (BMDP 4M), based on mean harmonic amplitude values for each sample, was used to identify sample groups, which, in turn, served to define the probable sources. Multivariate analysis of variance indicated how much of the shape information was explained by each factor or variable, and was also used to facilitate the sedimentologic interpretation of one factor (roughness). Levine's F-test was used to determine whether or not the explained variance for each of the 23 shape variables (harmonics) is statistically significant. Levine's F-test also was used to measure the difference between sample values resulting from analysis of variance. Discriminate function analysis was used to estimate the percentage of sand derived from each of the potential sources. The beach sand at Creciente Island has two primary sources. The first is the inner continental shelf, which contributed from approximately 50 to $57 \%$ of the sand in observed samples. The second source is the nearby rivers, which contributed from 43 to $50 \%$.
\end{abstract}

\section{RESUMEN}

El análisis de Fourier para forma de grano (AFFG) de cuarzo detrítico fue utilizado para identificar fuentes locales de arena de grano medio $(0.25$ a $0.50 \mathrm{~mm})$ en la isla de barrera Creciente, que se localiza en la costa occidental de Baja California Sur, México. Un total de 52 muestras de arena fueron obtenidas en isla Creciente y su alrededor. Los resultados de AFFG incluyen valores de amplitud media de armónicos, los cuales pueden ser empleados para caracterizar la composición de forma para cada muestra. Estos valores se usaron en programas estadísticos para identificar fuentes de abastecimiento de arena. El análisis de factores (BMDP $4 \mathrm{M}$ ), basado en los valores medios de amplitud de armónicos para cada muestra, fue usado para identificar grupos de muestras, las cuales sirvieron para definir las fuentes probables de abastecimiento. El análisis multivariado de varianza indicó cuánta información de forma del grano es explicada para cada factor o variable y también se utilizó para facilitar la interpretación de un factor (aspereza). La prueba $F$ de Levin se usó para determinar si la 
varianza explicada para cada una de las 23 variables de forma (armónicos) era o no era estadísticamente significativa. La prueba $\mathrm{F}$ de Levin se usó también para medir la diferencia entre valores de muestras resultantes del análisis de varianza. Se utilizó la función discriminante para estimar el porcentaje de arena derivado de cada posible fuente potencial. La arena de playa de isla Creciente tiene dos principales fuentes de abastecimiento. La primera es de la plataforma continental interna, que contribuye aproximadamente con 50 a $57 \%$ de la arena de las muestras observadas. La segunda es de los ríos locales, que contribuyen entre el 43 y $50 \%$.

\section{INTRODUCTION}

The identification of sediment sources for beach sand is a topic of considerable importance because correct identification provides the basis for the computation of meaningful sediment budgets, which, in turn, are necessary for proper beach regulation and management. Although mineralogic information may be useful to identify the type of ultimate crystalline source rocks (protolith), net sediment transport pathways and boundaries of some littoral segments, such data have proved inadequate as a basis for quantitative budget analysis due to differences in size, density and shape of constituent grains.

Schwarcz and Shane (1969), as well as Ehrlich and Weinberg (1970) describe a closedform Fourier method to analyze the observed variation of two-dimensional, maximum-projection, grain outline. Grain shape may be estimated by an expansion of the periphery radius as a function of angle about the grain's center of gravity by a Fourier series. In Fourier grain-shape analysis, variations in grain size and density are controlled by using a restricted grain-size interval $(0.25-0.5 \mathrm{~mm})$ of one detrital mineral (normally quartz), therefore grain shape is the principal remaining source of variation.

Populations of detrital quartz grains possess shape-frequency distributions just as they possess size-frequency distributions. The source and transport history can be deciphered from shape compositional data. Fourier analysis allows partitioning of the maximum projection outline of a quartz (or any other) grain into a series of shape components which converge to the empiric shape. The contribution of each harmonic or wave number to empiric shape is known as its harmonic amplitude value (Ehrlich et al., 1980). For example, the amplitude value for the second harmonic represents the contribution of a "figure eight" to the empiric shape, and

\section{INTRODUCCION}

La identificación de fuentes de abastecimiento de arena de playa es un tema de considerable importancia, debido a que la identificación precisa de la fuente de origen proveé las bases para el cálculo significativo del balance del sedimento, el cual es necesario para el manejo y regulación adecuados de las playas. A pesar de que la información mineralógica puede ser útil para identificar el tipo de fuente de roca cristalina (protolito), trayectorias de transporte neto de sedimento y los límites de algunos segmentos litorales, todos estos datos han probado ser inadecuados para usarse como base en el análisis cuantitativo de balance de sedimentos, debido a las diferencias en tamaño, densidad y forma de la constitución de los granos.

Schwarcz and Shane (1969), así como Ehrlich y Weinber (1970) describen un método de Fourier de forma cerrada para analizar la variación observada en la proyección máxima en dos dimensiones del contorno de grano. La forma del grano puede ser estimada, a partir de una expansión de la periferia del radio, como función del ángulo cerca del centro de gravedad del grano, por medio de una serie de Fourier. En el análisis de Fourier para forma de grano, las variaciones en tamaño de grano y densidad se controlan usando un intervalo de tamaño restringido $(0.25$ a $0.05 \mathrm{~mm})$ de grano de mineral detrítico (normalmente cuarzo), por tanto, la forma del grano es la principal fuente de variación remanente.

Las poblaciones de granos de cuarzo poseen distribuciones de frequencia de forma así como distribuciones de frecuencia de tamaño. El origen e historia del transporte de un grano puede descifrarse a partir de los datos de composición de forma. El análisis de Fourier permite la división de la máxima proyección de un contorno de grano de cuarzo (o cualquier otro) 
thus is a measure of grain elongation; the third harmonic represents the contribution of a trefoil (three-leaved clover); the fourth represents the contribution of a quadrefoil (four-leaved clover), etc. In general, the value for the $n$th harmonic amplitude represents the shape contribution of a figure with $n$ nodes.

Grain-shape studies completed on the Pacific coast of North America include Clark and Osborne (1982), Osborne and Cho (1989), Osborne et al. (1989), Osborne et al. (1990), Osborne and Yeh (1991), Murillo (1993), Lu (1992), and Osborne et al. (1993).

\section{STUDY AREA}

Creciente Island is located on the west coast of the peninsula of Baja California Sur, Mexico, north of $\mathrm{La} \mathrm{Paz}$, between latitude $25^{\circ} 43^{\prime}, 24^{\circ} 18^{\prime} \mathrm{N}$ and longitude $112^{\circ} 18^{\prime}$, $111^{\circ} 23^{\prime} \mathrm{W}$ (Fig. 1). The island is about $20 \mathrm{~km}$ long; the western portion is $2 \mathrm{~km}$ wide and narrows to the east to about $100 \mathrm{~m}$. The exposed beach along the south coast of the island is about 50 to $80 \mathrm{~m}$ wide.

Creciente Island is a sandy barrier, built mostly of medium-grained sand. Its surface includes a series of beach ridges with partially stabilized dunes. The beach along the north coast of the island is bordered by mangrove swamps interrupted by tidal channels. The western portion is dominated by active dunes, from approximately 1.5 to $2.0 \mathrm{~m}$ high and oriented northwest. The dunes are stabilized by vegetation in the central and eastern part of the island (Fig. 1),

\section{GEOLOGICAL SETTING}

The Pacific continental shelf is from 50 to $70 \mathrm{~km}$ wide in the study area. The wave energy is high along the Pacific coast, and the winter storm-associated longshore currents, which flow to the southeast, are more persistent than spring currents. In Las Almejas Lagoon, the tide range varies from 1.4 to $1.8 \mathrm{~m}$, and associated current velocities are high. The highest current velocities ( 10 to $14 \mathrm{~cm} / \mathrm{s}$ ) occur at the inlet, and there is a regular decrease in velocity within en una serie de componentes de forma, que convergen en una forma empírica. La contribución de cada armónico o número de onda a una forma empírica es conocida como su valor de amplitud armónica (Ehrlich et al., 1980). Por ejemplo, el valor de amplitud para el segundo armónico representa la contribución de una "figura ocho" a la forma empírica, que es así una medida de alargamiento del grano; el tercer armónico representa la contribución de un trifoleado (trébol de tres hojas), el cuarto representa la contribución de un cuatrofoleado (trébol de cuatro hojas), etc. En general, los valores para la enésima amplitud armónica representan la contribución de la forma de una figura con $n$ nodos.

Entre los estudios de la forma de grano realizados en la costa del Pacífico de Norte América están los de Clark y Osborne (1982), Osborne y Cho (1989), Osborne et al. (1989), Osborne et al. (1990), Osborne y Yeh (1991), Murillo (1993), Lu (1992) y Osborne et al. (1993).

\section{AREA DE ESTUDIO}

La isla Creciente está localizada en la costa occidental del estado de Baja California Sur (México), al noroeste de la ciudad de La Paz, entre las latitudes $25^{\circ} 43^{\prime}$ y $24^{\circ} 18^{\prime} \mathrm{N}$ y longitudes $112^{\circ} 18^{\prime}$ y $111^{\circ} 23^{\prime} \mathrm{O}$ (Fig. 1). La isla tiene una longitud aproximada de $20 \mathrm{~km}$; la porción oeste tiene un ancho aproximado de $2 \mathrm{~km} \mathrm{y}$ se angosta hacia el este, donde mide cerca de $100 \mathrm{~m}$. La costa externa a lo largo de la costa sur de la isla tiene entre 50 y $80 \mathrm{~m}$ de ancho.

Isla Creciente es una isla de barrera arenosa, constituida principalmente de arena media. Su superficie está formada de una serie de cordones de playa con dunas parcialmente estabilizadas. La playa, a lo largo de la costa norte de la isla, está cubierta por pantanos de manglar, interrumpidos por canales de marea. La topografía de la porción oeste está dominada por dunas activas, que miden aproximadamente entre 1.5 y $2.0 \mathrm{~m}$ de alto, orientadas al noroeste. Las dunas están estabilizadas por vegetación en la parte central y este de la isla. 


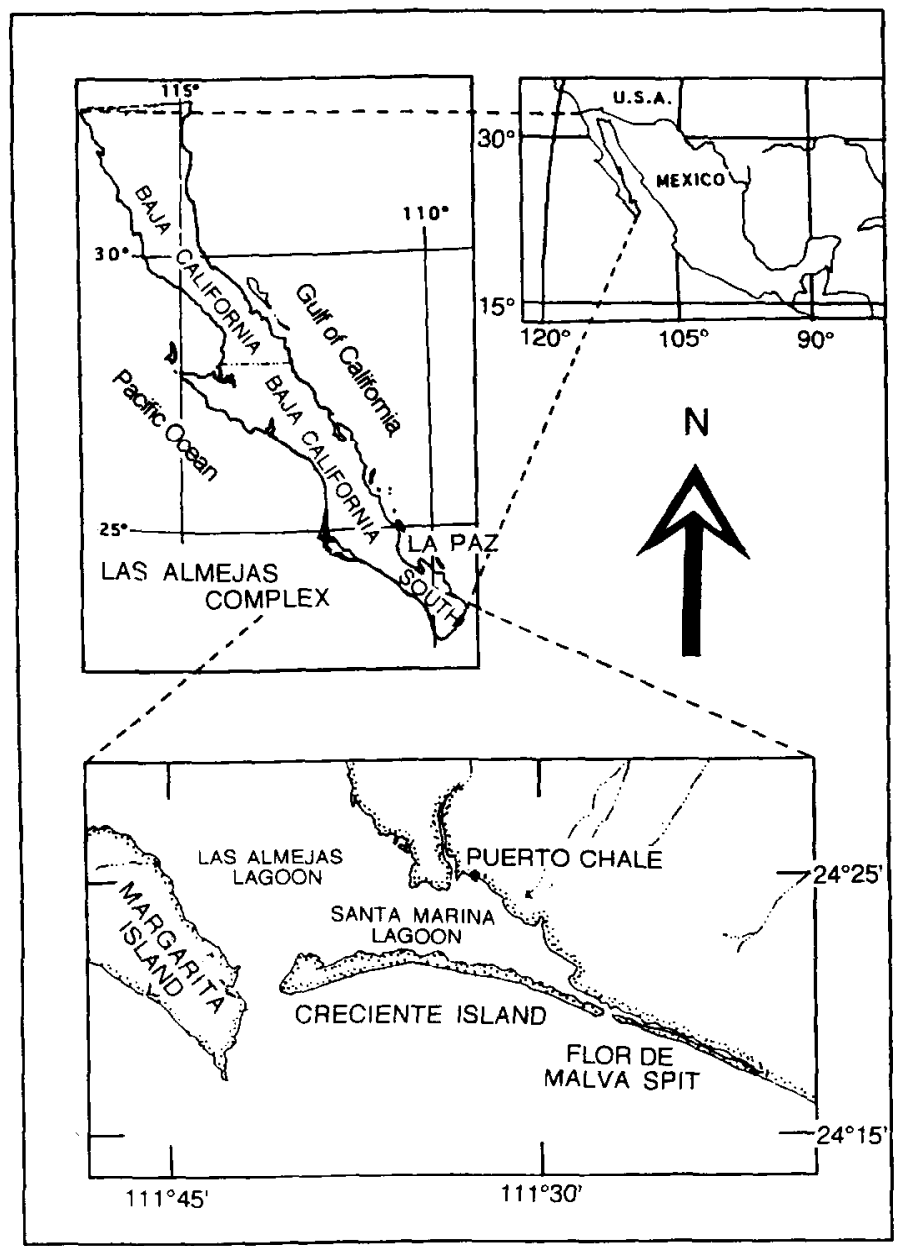

Figure 1. Location map of Las Almejas complex.

Figura 1. Mapa de localización del complejo Las Almejas.

the lagoon away from the inlet (Lankford, 1977).

In the study area, rivers flow to the Pacific Ocean from a divide along the eastern side of the peninsula. The La Presa and San Venancio rivers, which are the dominant streams in this area, erode mostly Miocene and Pliocene marine sandstone and conglomerate, Quaternary sandstone and Holocene eolian sediment.

\section{SEA LEVEL CIIANGE HISTORY}

During the Wisconsin glacial maximum about 18,000 years B.P., which is associated

\section{MARCO GEOLOGICO}

En el área de estudio, la plataforma continental tiene de 50 a $70 \mathrm{~km}$, aproximadamente, de ancho. La energía del oleaje es alta a lo largo de la costa del océano Pacífico, y las tormentas de invierno, asociadas a corrientes que fluyen al sureste a lo largo de la costa, son de mayor persistencia que las corrientes de primavera. En la laguna Las Almejas, el intervalo de marea varía de 1.4 a $1.8 \mathrm{~m}$, y las velocidades de corrientes asociadas son altas. Las velocidades mayores de corriente (10 a $14 \mathrm{~cm} / \mathrm{s})$ se presentan en las bocas de la laguna, y disminuyen paulatinamente 
with a $-130 \mathrm{msl}$ low-stand of sea level, the present continental shelf was exposed to terrestrial and atmospheric processes. Valleys and canyons were eroded, fluvial sedimentation occurred in flood plains and deltas, and weathering produced various soil horizons (Lankford, 1977).

The Holocene transgression began about 18,000 years B.P. and proceeded more rapidly than terrigenous sedimentation rates until about 5,000 years B.P. A thin blanket of transgressive sand covered the shelf. Topographic depressions were flooded and exposed to marine energy, and open ocean beaches commonly were built along the mainland shore of the present coastal lagoons (Lankford, 1977).

When the transgression slowed about 5,000 years B.P. at a level of -3 to $-4 \mathrm{msl}$, barrier-building processes began to enclose narrow portions of nearshore areas. The shoreline slowly prograded in response to a reduced rate of sea level rise and a continued supply of terrigenous sediment (Lankford, 1977).

\section{SAMPLING AND METHODOLOGY}

A total of 52 samples from different environments were selected for Fourier grain-shape analysis. Surface and core samples were collected from beaches, coastal dunes, the inner continental shelf, lagoons, and the beds of intermittent streams. These samples were collected in four field trips: 1) October 1990 for beach and bottom samples, 2) April 1991 for beach and shelf samples, and 3) and 4) in July 1991 for subsurface samples (Fig. 2).

Surface beach samples were collected using a $10 \times 10 \times 10 \mathrm{~cm}$ aluminum cubic sampler to obtain about $0.8 \mathrm{~kg}$ of sample. Vibracore samples were obtained using a Dreyer LittleChamp Gasoline Concrete Vibrator. River samples were collected using a manual cone-andquarter splitting technique, and shelf samples were recovered by using a Van Veen dredge at a depth of $-10 \mathrm{~m}(\mathrm{msl})$, which occurs approximately $70 \mathrm{~m}$ off the coast.

\section{Sample preparation}

Detrital quartz grains constitute the only mineral examined by Fourier analysis. As grain shape varies with grain size (Liu, 1993), según se alejan de las bocas (Lankford, 1977).

En el área de estudio, los ríos fluyen al océano Pacífico a partir de los parteaguas del lado este de la península. Los ríos La Presa y San Venancio, que son los arroyos dominantes en esta área, están erosionando principalmente rocas sedimentarias marinas y conglomerados del Mioceno y Plioceno, así como areniscas del Cuaternario y sedimento eólico del Holoceno.

\section{HISTORIA DE LOS CAMBIOS DEL NIVEL DEL MAR}

Durante el epiosodio de nivel del mar a $-130 \mathrm{~m}$, asociado con la máxima glaciación Wisconsiana, hace 18,000 años A.C., la plataforma continental presente estuvo expuesta a procesos atmosféricos y terrestres. Valles y cañones fueron erosionados, ocurrió sedimentación fluvial en planicies de inundación y deltas, y el intemperismo produjo zonas de suelo (Lankford, 1977).

La transgresión del Holoceno comenzó hace 18,000 años A.C. y avanzó más rápidamente que la tasa de depositación de sedimento terrigeno hasta hace 5,000 años A.C. Una cubierta delgada de arena transgresiva cubrió la plataforma. Depresiones topográficas fueron inundadas y expuestas a energía marina, y playas de mar abierto se formaron a lo largo de la costa de tierra firme de las lagunas costeras presentes (Lankford, 1977).

Cuando la transgresión marina disminuyó, hace cerca de 5,000 años A.C., y el nivel del mar estaba entre los -3 y $-4 \mathrm{~m}$, comenzó la construcción de barreras y encerramiento de porciones estrechas de áreas cercanas a la costa. La orilla de la costa lentamente progradó, en respuesta a la reducida tasa de incremento del nivel del mar y al continuo abastecimiento de sedimento terrigeno (Lankford, 1977).

\section{MUESTREO DE CAMPO Y METODOLOGIA}

Un total de 52 muestras de diferentes ambientes fueron seleccionadas para el análisis de Fourier de forma de grano. Las muestras superficiales y de núcleo fueron recolectadas en las playas, dunas costeras, plataforma continental interna, lagunas y lechos de arroyos intermi- 


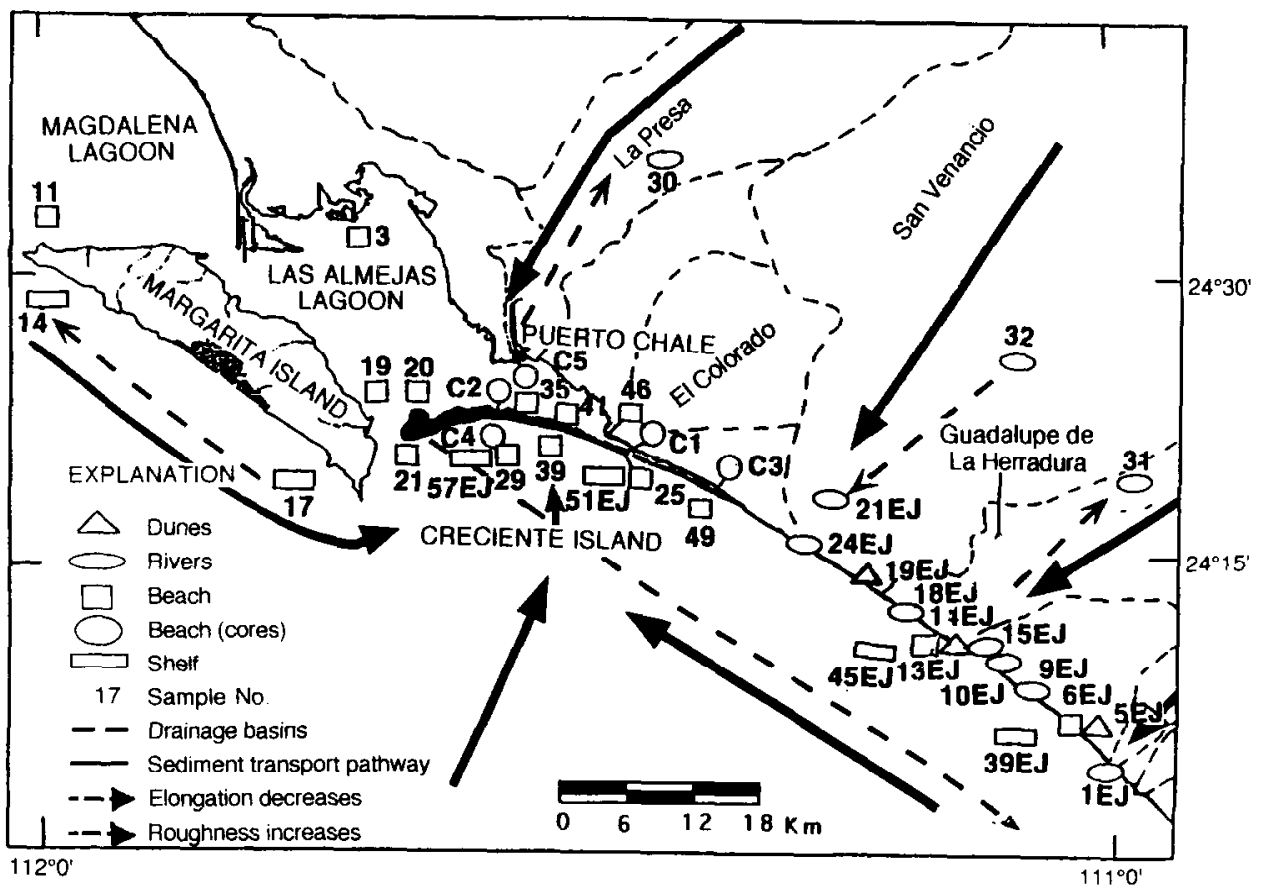

Figure 2. Location of samples used for grain-shape analysis and associated trends for grain asperity (roughness), elongation and inferred transport directions.

Figura 2. Localización de las muestras usadas en el análisis de forma de grano y tendenciass asociadas con aspereza de grano (irregularidad), alargamiento y direcciones de transporte inferidas.

only the medium sand fraction $0.25-0.50 \mathrm{~mm}$ $(1.0-2.0 \phi)$ from each sample was used. The samples were first wet-sieved to obtain approximately $100 \mathrm{~g}$ of desired size fraction; wet sieving was used to minimize breakage and attrition of the quartz grains. Sieving was followed by drying in a convection oven at $40^{\circ} \mathrm{C}$. Strongly magnetic minerals were removed from the samples using a hand magnet. The samples then were boiled in a solution of $10 \%$ hydrochloric acid with stannous chloride crystals for 20 minutes to remove any iron-oxide coating and carbonate cement (Carver, 1971). The hydrochloric acid residue was removed by rinsing the samples in deionized water. Quartz grains were then etched clean by washing them in a hydrofluoric acid bath for one minute. Such etching does not significantly alter the grain shape of detrital quartz (Schultz, 1980). All samples were then rinsed in deionized water and dried thoroughly. Samples were examined under a stereoscopic tentes. Estas muestras fueron tomadas en cuatro salidas al campo: 1) octubre 1990, para obtener muestras de playa y fondo marino, 2) abril 1991, para muestras de playa y plataforma, y 3) y 4) en julio de 1991, para muestras de núcleo (Fig. 2).

Las muestras de playa superficial se obtuvieron usando un cubo de aluminio de $10 \times$ $10 \times 10 \mathrm{~cm}$, para obtener cerca de $0.8 \mathrm{~kg}$ por muestra. Los núcleos se obtuvieron con un vibrador para concreto, de gasolina, tipo Dreyer Little-Champ. Las muestras de ríos se obtuvieron mediante la técnica de cuarteado y las muestras de plataforma, con una draga tipo Van Veen, a una profundidad de $10 \mathrm{~m}(\mathrm{nmm})$ y a una distancia aproximada de la costa de $70 \mathrm{~m}$.

\section{Preparación de la muestra}

Cuarzo detrítico fue el único mineral analizado mediante Fourier para forma de grano. 
microscope using a reflecting light source. For each sample, two hundred quartz grains were picked using a very small brush, and were placed on a glass slide for digitizing.

\section{Equipment (optical digitizer)}

The hardware associated with shape analysis system in the Sedimentary Petrology Laboratory at the University of Southern California includes a petrographic microscope, video camera, and VAX station 3200. The VAX station 3200 is a stand-alone, 32-bit work-station based on the KA650 Central Processing Unit (CPU). The system comes with as much as 16 megabytes of operating memory. Other system components include a 19-inch diagonal monochrome monitor, a mouse, a keyboard, a video subsystem module, an ethernet communications module and optical diskette driver (Osborne and Ych, 1991).

\section{Procedure}

Digitizing of the individual quartz grains is accomplished using an optical digitizer and the Grab, Boundary and Write Fortran program written by Tim Fogarty. In this process, a black and white camera projects the maximum twodimensional image of the quartz grain from a standard binocular petrographic microscope to a video screen. The image of the grain appears dark in relation to the surrounding background since the petrographic microscope is lighted from below. A maximum contrast between grain edge and background allows the computer to scan the pixels of the video image and record all boundary points of the grain as Cartesian coordinates ( $\mathrm{X}-\mathrm{Y}$ coordinates). A pixel is determined as a boundary point if it is dark and one of its neighbors is light. While the Cartesian coordinates are computed, the centroid of the projected grain also is computed (Osborne and Yeh, 1991). The data are stored on the VAX station 3200 and optical discs.

\section{RESULTS}

A series of statistical procedures were performed to reduce and interpret the grain-shape data. The tests were run with the Biomedical
Como la forma de grano varía con el tamaño (Liu, 1993), sólo la fracción de 0.25 a $0.50 \mathrm{~mm}$ ( 1.0 a $2.0 \phi$ ) fue usada para cada muestra. Primero, las muestras fueron tamizadas húmedas para obtener $100 \mathrm{~g}$ aproximadamente del tamaño deseado. Se tamizaron húmedas con el fin de reducir la ruptura y fricción entre los granos. El tamizado fue seguido por secado en horno de convección a $40^{\circ} \mathrm{C}$. Los minerales magnéticos se removieron con un imán de mano. Con objeto de limpiar los granos de cuarzo de residuos de óxidos de fierro y carbonatos, cada muestra se hirvió en una solución al $10 \%$ de ácido hidroclorhidrico con perlas de cloruro estañoso, durante 20 minutos (Carver, 1971) y se enjuagó con agua destilada. Posteriormente, para identificar claramente los granos de cuarzo entre otros minerales, la muestra se humedeció en ácido hidrofluorídrico, que corroe los minerales sin alterar significativamente la forma del grano (Schults, 1980). Las muestras se cnjuagaron y secaron; después, se examinaron en un microscopio petrográfico, usando una fuente ligeramente reflejante. Para cada muestra, se seleccionaron doscientos granos de cuarzo con un pincel y se montaron en un portaobjetos para la digitalización.

\section{Equipo (digitalizador óptico)}

El equipo electrónico asociado con el sistema de análisis de forma, en el Laboratorio de Petrología Sedimentaria de la Universidad del Sur de California, incluye microscopio petrográfico, cámara de video y unidad VAX 3200 de almacenamiento de datos. Esta última es una estación de trabajo de 32 bits, con base en la unidad central de procesamiento KA650 (UCP). El sistema viene con 16 megabytes de memoria operable. Otros componentes del sistema son un monitor monocromático de 19 pulgadas, ratón, teclado, módulo de video de subsistema, módulo de comunicación ethernet y unidad de disco óptico (Osborne y Yeh, 1991).

\section{Procedimiento}

La digitalización de granos individuales de cuarzo con el digitalizador óptico se realizó usando el programa en Fortran Grab, boundary and write, escrito por Tim Fogarty. En este pro- 
Data Processing Program (BMDP) (Dixon, 1990). These are: $4 \mathrm{M}$ factor analysis (Q-mode, maximum variance principal component analysis), 7D analysis of variances (one-way and two-way ANOVA), discriminate function analysis (DFA), and significance testing (F-test) (Davis, 1986).

\section{Factor analysis}

Introduction

Factor analysis is a very useful technique to identify differences in shape composition among samples from a common or from different depositional environments (Clark and Osborne, 1982; Osborne and Cho, 1989; Osborne et al., 1990). Two theoretical variables or factors commonly explain much of the grain-shape information. The physical meaning of a given factor may be inferred by comparing the mean amplitude value for each harmonic for the endmember samples associated with each factor. Mean amplitude values for each sample were used as the input for factor analysis. Standardized scores obtained from this analysis are listed in table 1 and were used to contruct Fig. 3.

\section{End-members}

The two end-member samples for each factor are shown in Fig. 3. The end-members are those samples with highest and lowest values for factors 1 and 2, respectively. These samples represent the most different shape compositions with respect to each of these factors. The endmembers associated with factor 1 are samples $17(-1.33)$ and $21 \mathrm{EJ}(3.33)$, which are from the inner continental shelf and San Venancio River, respectively. The quartz grains in sample 17 (shelf) are triangular to spherical, smooth and gray. The quartz grains in sample 2IEJ (river) tend to be triangular and clear with conchoidal fracture and rough edges. The endmembers for factor 2 are samples 45EJ (-1.63) and 10EJ (2.03), which are from the inner shelf and an unnamed river, respectively. Sample $45 \mathrm{EJ}$ (shelf) is enriched in gray, triangular to spherical grains with rounded edges and smooth outlines, but some clear grains with sharp edges and rough outlines occur. End-member sample ceso, una cámara proyecta en blanco y negro las dos dimensiones máximas de la imágen del grano del cuarzo, a partir de un microscopio binocular petrográfico, en una pantalla de video. La imágen de los granos aparece obscura en relación con su rededor, ya que el microscopio ilumina por debajo. Un contraste máximo entre las orillas de los granos y su rededor permite a la computadora rastrear los puntos de la imágen de video y registrar todos los puntos del contorno de los granos como coordenadas cartesianas (coordenadas X-Y). Cada punto de la imagen está determinado como un punto delimitador si éste es obscuro y su vecino claro. A la vez que las coordenadas cartesianas son computadas, se computan también los centros del grano proyectado (Osborne y Yeh, 1991). Los datos se almacenan en la estación VAX3200 y un disco óptico.

\section{RESULTADOS}

Se utilizaron una serie de procedimientos estadísticos para reducir e interpretar los datos sobre la forma de grano. Las pruebas fueron computadas con el programa de procesamiento de datos biomédicos (BMDP) (Dixon, 1990). Estas fueron: análisis de factores $4 \mathrm{M}$ (en modo $\mathrm{Q}$, análisis de componentes principales de varianza máxima) análisis de varianza $7 \mathrm{D}$ (ANVA, una y dos vías), análisis de función discriminante (AFD) y la prueba de significación (prueba F) (Davis, 1986).

\section{Análisis de factores}

Introducción

El análisis de factores es una técnica útil para identificar diferencias en composición de forma, entre muestras de un ambiente común o diferente (Clark y Osborne, 1982; Osborne y Cho, 1989; Osborne et al., 1990). Comúnmente, dos variables teóricas o factores explican la mayor parte de la información sobre la forma de grano. El significado fisico de un factor dado puede inferirse a través de la comparación del valor de la amplitud de la media para cada armónico de las muestras terminales asociadas con cada factor. Los valores de amplitud media de cada muestra se usaron como entrada de da- 
Murillo et al.: Sources of beach sand at Creciente Island: Fourier grain-shape analysis

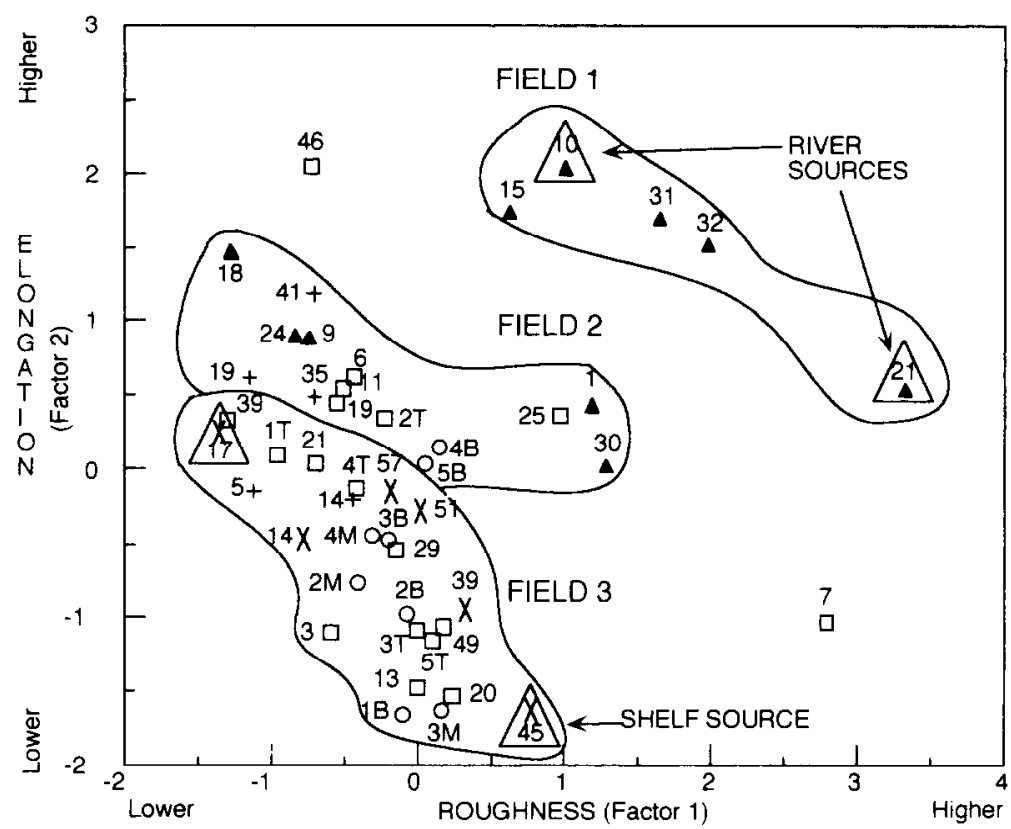

\section{Explanation}

- River samples

口 Beach samples

- Old beach samples

$X$ Shelf samples

+ Dune samples

7 Sample number

21 EJ samples

$\triangle$ End members

$T$ Core top

$M$ Core middle

B Core bottom

Figure 3. Bivariate plot showing the results of Q-mode factor analysis of Fourier grain-shape data for sediment samples collected within Las Almejas complex.

Figura 3. Diagrama bivariado con los resultados del análisis de factores, en modo $Q$, de datos de Fourier para forma de grano, de muestras de sedimentos recolectadas en el complejo Las Almejas.

$10 \mathrm{EJ}$ (river) is enriched in triangular to tabular, clear to gray quartz grains with rough edges. SEM photomicrographs for typical grains from the end-member samples are shown in Fig. 4. Figure 5 shows a photomicrograph of part of the detrital quartz grain shown in Fig. 4B.

Factor 1 explains approximately $61 \%$ of the total sample variance and factor 2 explains $33 \%$. These percentages indicate that factor 1 is nearly twice as important as factor 2 .

\section{Analysis of variance (ANOVA)}

A series of significance tests were performed to interpret the theoretical sedimentologic variables derived from factor analysis. An F-test was computed using the 200 values for each harmonic associated with pairs of endmember samples obtained by factor analysis. Grain-shape studies by Ehrlich and Weinberg (1970) relate the outline of the grains with har- tos para el análisis de factores. Los valores estandarizados obtenidos de este análisis se listan en la tabla 1 y se usaron para hacer la Fig. 3.

Miembros terminales

Las dos muestras de los miembros terminales para cada factor se presentan en la Fig. 3. Las muestras miembros terminales son aquéllas que obtienen el valor más alto y más bajo en los factores 1 y 2 . Estas muestras representan la composición de forma más diferente entre todo el conjunto de muestras, con respecto a cada uno de estos factores. Las muestras terminales asociadas con el factor 1 son las muestras 17 $(-1.33)$ y $21 \mathrm{EJ}(3.33)$, las cuales son de la plataforma continental interna y del rio San Venancio, respectivamente. Los granos de cuarzo en la muestra 17 (plataforma) son de triangulares a esféricos, lisos y grises. Los granos de cuarzo en la muestra 21 EJ (río) tienden a ser triangu- 
Table 1. Factor analysis data (standardized scores) from Fourier grain-shape analysis of mediumgrained sand samples collected within Las Almejas complex

Tabla 1. Datos del análisis de factores (resultados estandarizados), derivados del análisis de Fourier para forma de grano de muestras de arena de grano mediano recolectadas en el complejo Las Almejas.

A

\begin{tabular}{ccc} 
Core samples & Factor 1 & Factor 2 \\
\hline C1T & -0.97 & 0.11 \\
C1B & -0.09 & -1.66 \\
C2T & -0.23 & 0.35 \\
C2M & -0.40 & -0.77 \\
C2B & -0.06 & -0.98 \\
C3T & 0.00 & -1.09 \\
C3M & 0.18 & -1.63 \\
C3B & -0.19 & -0.48 \\
C4T & -0.42 & -0.13 \\
C4M & -0.30 & -0.45 \\
C4B & 0.15 & 0.15 \\
C5T & 0.09 & -1.16 \\
C5B & 0.06 & 0.03 \\
\hline
\end{tabular}

$\mathrm{C}$

\begin{tabular}{ccc} 
Shelf samples & Factor 1 & Factor 2 \\
\hline 14 & -0.78 & -0.47 \\
17 & -1.33 & 0.26 \\
$39 \mathrm{EJ}$ & 0.33 & -0.93 \\
$45 \mathrm{EJ}$ & 0.77 & -1.64 \\
$51 \mathrm{EJ}$ & 0.03 & -0.28 \\
$57 \mathrm{EJ}$ & -0.17 & -0.15 \\
\hline
\end{tabular}

D

\begin{tabular}{ccc} 
Dune samples & Factor 1 & Factor 2 \\
\hline $5 \mathrm{EJ}$ & -1.11 & -0.14 \\
$14 \mathrm{EJ}$ & -0.44 & -0.20 \\
$19 \mathrm{EJ}$ & -1.15 & 0.63 \\
35 & -0.70 & 0.49 \\
41 & -0.71 & 1.19 \\
\hline
\end{tabular}

B

\begin{tabular}{ccc} 
Beach samples & Factor 1 & Factor 2 \\
\hline 3 & -0.59 & -1.11 \\
$6 \mathrm{EJ}$ & -0.43 & 0.63 \\
7 & 2.79 & -1.03 \\
$11 \mathrm{~A}$ & -0.55 & 0.45 \\
$13 \mathrm{EJ}$ & 0.00 & -1.47 \\
19 & -0.51 & 0.55 \\
20 & 0.23 & -1.53 \\
21 & -0.69 & 0.05 \\
25 & 0.97 & 0.37 \\
29 & -0.15 & -0.55 \\
39 & -1.30 & 0.33 \\
46 & -0.72 & 2.04 \\
49 & 0.18 & -1.05 \\
\hline
\end{tabular}

E

\begin{tabular}{ccc} 
River samples & Factor 1 & Factor 2 \\
\hline $1 \mathrm{EJ}$ & 1.18 & 0.43 \\
$9 \mathrm{EJ}$ & -0.83 & 0.89 \\
$10 \mathrm{EJ}$ & 1.01 & 2.03 \\
$15 \mathrm{EJ}$ & 0.63 & 1.73 \\
$18 \mathrm{EJ}$ & -1.27 & 1.46 \\
$21 \mathrm{EJ}$ & 3.33 & 0.54 \\
$24 \mathrm{EJ}$ & -0.74 & 0.88 \\
30 & 1.28 & 0.02 \\
31 & 1.98 & 1.51 \\
32 & 1.64 & 1.70 \\
\hline
\end{tabular}


monics. The lower harmonics (i.e., harmonics 2 through 6) are fundamental shape components with few nodes, and thus serve as measures of gross grain shape or form (circular, elliptical, triangular, etc.). The higher harmonics (e.g., harmonics 8 through 20) are shape components with many smaller nodes, and thus serve as measures of fine shape (asperity or roughness). Inasmuch as the higher harmonics measure asperity along the entire grain outline rather than just at grain edges, the concept of grain asperity or roughness is distinct from the traditional concept of grain roundness.

Levine's F-test was used to determine whether or not the differences in mean amplitude values for each harmonic associated with the end-member pairs for each factor are statistically significant. At least 200 harmonic amplitude values were used for each end-member sample. The tail probabilities obtained from such significance testing for factor 1 samples are listed in table 2. Tail probabilities less than 0.01 indicate highly significant differences; tail probabilities from 0.01 to 0.05 indicate significant differences, and tail probabilities greater than 0.05 indicate that the obtained values are not significantly different. Levine's tail probability values for the end-member samples associated with factor 1 [samples 17 (inner shelf) and $21 \mathrm{EJ}$ (river)] show significant or highly significant differences for harmonics 7 through 24 , which indicates that grain asperity or roughness is the dominant source of variation. Therefore, based on differences in sample variance, factor 1 may be interpreted as representing grain asperity or roughness. For factor 2 [samples $10 \mathrm{EJ}$ (river) and 45EJ (inner shelf)], no statistically significant F-value occurs between endmembers $10 \mathrm{EJ}$ and $45 \mathrm{EJ}$ for harmonics 2 through 6; hence, with this test there is no basis for interpreting that this factor is a form component. Therefore, the univariate form of the Hotelling $\mathrm{T}^{2}$ test was used to evaluate differences in sample means for each of the lower harmonics. The results obtained from this test are given in table 3, which shows that statistically significant differences occur for the means of each of harmonics 2 through 6 for the end-member samples associated with factor 2 . Therefore, factor 2 may be interpreted as a measure of grain form (sphericity). Inasmuch as lares y claros con fractura concoide y orillas ásperas. Las muestras terminales asociadas con el factor 2 son las muestras $45 \mathrm{EJ}(-1.63)$ y $10 \mathrm{EJ}$ (2.03), las cuales fueron obtenidas en plataforma y río (sin nombre), respectivamente. La muestra $45 \mathrm{EJ}$ (plataforma) está enriquecida en granos grises de triangulares a esféricos con orillas redondeadas y contornos lisos, pero algunos granos son claros con orillas definidas y contornos ásperos. La muestra terminal 10EJ (río) está enriquecida en granos de triangulares a tabulares, de claros a grises, con orillas ásperas. Microfotografias de los granos típicos de las muestras miembros terminales se presentan en la Fig. 4. La Fig. 5 expone la microfotografia de una porción del grano de cuarzo detrítico de la Fig. 4B.

El factor 1 explica el $61 \%$ de la varianza total de la muestra y el factor 2 explica el $33 \%$. Estos porcentajes indican que el factor 1 es casi dos veces más importante que el factor 2 .

\section{Análisis de varianza (ANVA)}

Se hizo una serie de pruebas de significación para interpretar las variables sedimentológicas teóricas derivadas del análisis de factores. Una prueba $\mathrm{F}$ fue computada usando los 200 valores de cada armónico asociado con pares de muestras miembros terminales obtenidas del análisis de factores. Los estudios de forma de grano de Ehrlich y Weingerg (1970) relacionan el contorno de los granos con armónicos. Los armónicos pequeños (armónicos 2 al 6) son componentes fundamentales de forma con pocos nodos y, por tanto, sirven como una medida de forma de grano burda o forma (circular, elíptica, triangular, etc.). Los armónicos grandes (armónicos 8 al 20) son componentes de forma con muchos nodos más pequeños $\mathrm{y}$, por tanto, sirven como una medida de forma fina (aspereza o irregularidad). En tanto que los armónicos más grandes miden aspereza a lo largo de todo el contorno del grano y no sólo en las orillas, el concepto de aspereza o irregularidad es distinto del concepto tradicional de redondez del grano.

La prueba $F$ de Levin se utilizó para determinar si las diferencias en valores de amplitud, para cada armónico asociado con los pares de muestras de los miembros terminales para cada 


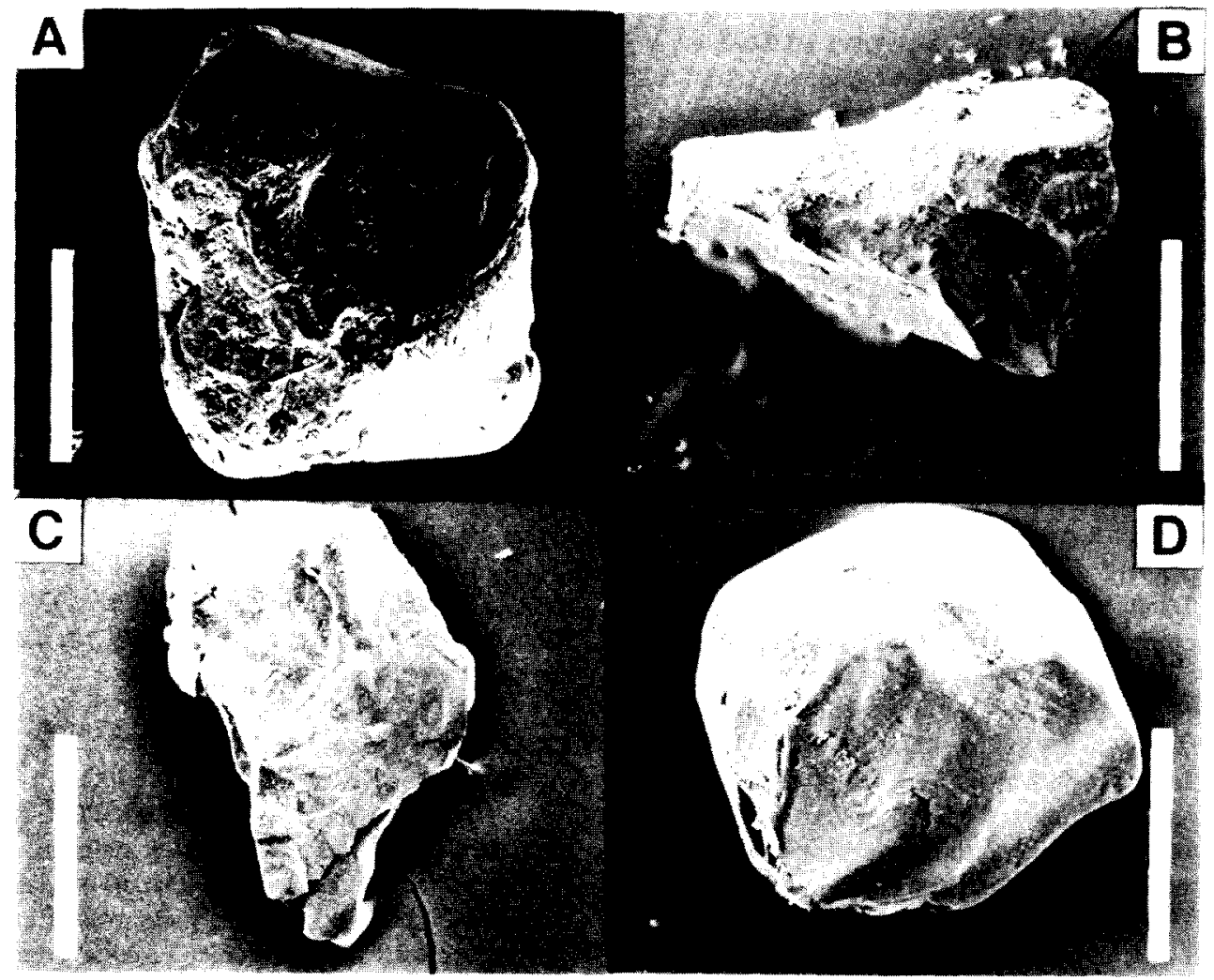

Figure 4. SEM photomicrographs of detrital quartz sand grains associated with end-member samples. Characteristic abraded, smooth grain (A) from shelf sample 17 and rough grain (B) from river sample 21 associated with factor 1 . Scale bars for $A$ and $B$ are 200 and $500 \mu \mathrm{m}$, respectively. Typical elongate grain (C) from river sample 10EJ and equant grain (D) from shelf sample 45EJ associated with factor 2. Scale bars for $C$ and $D$ are 500 and $200 \mu \mathrm{m}$, respectively.

Figura 4. Microfotografias de MRE de los granos de arena de cuarzo detrítico asociados con muestras miembros terminales. Grano característico, desgastado y liso (A), de la muestra 17 de plataforma y grano áspero (B) de la muestra de río 21, asociadas con el factor 1. Las barras de escala para A y B son de 200 y $500 \mu \mathrm{m}$, respectivamente. Grano alargado típico (C) de la muestra de río $10 \mathrm{EJ}$ y grano equidimensional (D) de la muestra de plataforma 45EJ, asociadas con el factor 2 . Las barras de escala para C y D son de 500 y $200 \mu \mathrm{m}$, respectivamente.

the greatest difference in the end-member samples is associated with harmonic 2 (table 3), this factor mostly represents a measure of grain elongation.

\section{Shape grouping}

Three major shape compositional fields are illustrated in Fig. 3. Field 1 represents grain factor, eran o no estadísticamente significativas. Por lo menos 200 valores de amplitud de armónicos fueron usados para cada muestra miembro terminal. Las colas de probabilidad obtenidas con esta prueba de significación para muestras del factor 1 se listan en la tabla 2. Las colas de probabilidad menores de 0.01 indican que las diferencias son altamente significativas; las colas de probabilidad entre $0.01 \mathrm{y}$ 


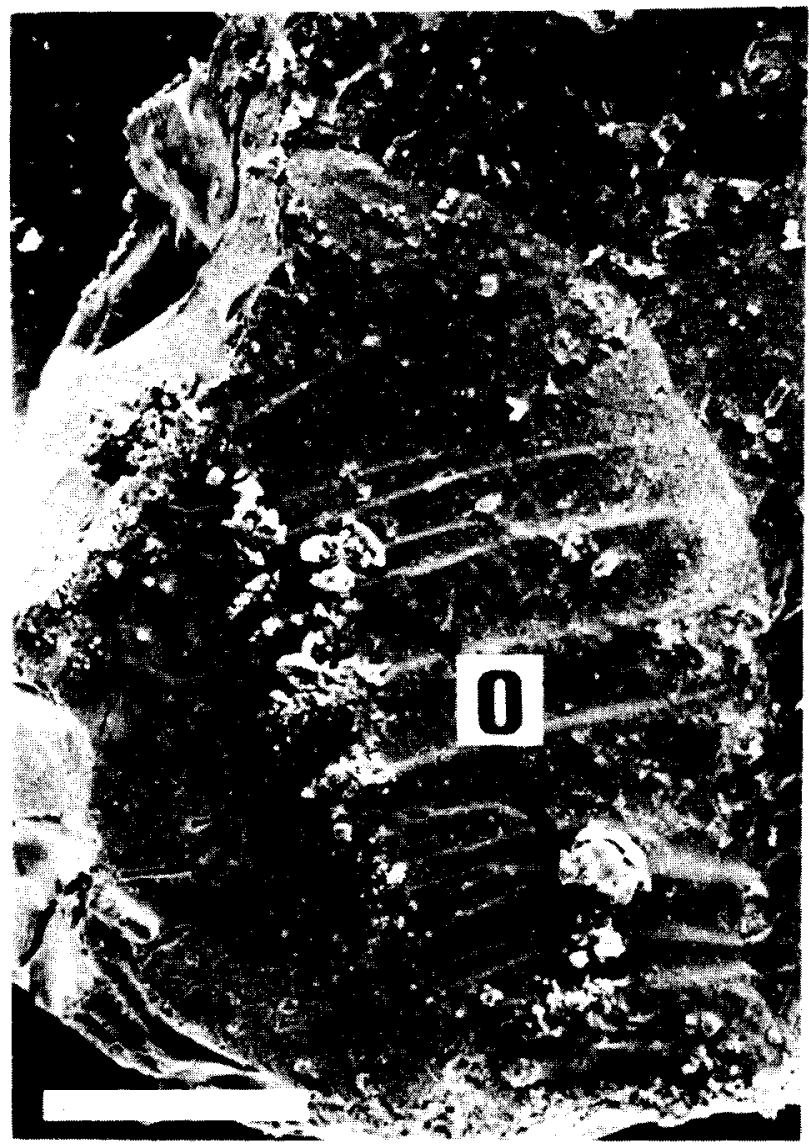

Figure 5. SEM photomicrograph of the detrital quartz grain from river sample 21EJ shown in Fig. 4B. Curvilinear lines indicate conchoidal fractures, which are partially coated by spherical masses of opaline cement (o). Scale bar is $50 \mu \mathrm{m}$.

Figura 5. Microfotografia de MRE de un grano de cuarzo detrítico de la muestra de río 21EJ, presentada en la Fig. 4B. Las líneas curvas indican fracturas concoides, que están parcialmente cubiertas por masas esféricas de cemento opalino (o). La barra de escala es de $50 \mu \mathrm{m}$.

shapes with high elongation and asperity (roughness) values characterized by river samples; field 2 represents shapes with intermediate elongation and low to high asperity values and constitutes a mixture of river, dune and beach environments, and field 3 represents shapes of low elongation and low roughness values, which are typical in samples from the inner continental shelf. River end-member samples (10EJ and 21EJ) are included in field 1, and shelf end-member samples (45EJ and 17) are included in field 3 .
0.05 indican diferencias significativas, $y$ colas de probabilidad mayores de 0.05 indican que el valor obtenido no es significantivamente diferente. Los valores de la prueba de Levin para las muestras miembros terminales asociadas con el factor 1 [muestras 17 (plataforma interna) y $21 \mathrm{EJ}$ (río)] muestran diferencias significativas o altamente significativas para los armónicos 7 a 24 , lo cual indica que la aspereza de los granos o irregularidad es la fuente de variación dominante. Por tanto, con base en diferencias en la varianza de muestras, el factor 1 puede ser in- 
Table 2. Results of harmonic amplitude values associated with end-member samples collected from Las Almejas complex.

Tabla 2. Resultados de los valores de amplitud de armónicos asociados con las muestras miembros términales recolectadas en cl complejo Las Almejas.

\begin{tabular}{|c|c|c|c|c|}
\hline \multicolumn{5}{|c|}{ Factor 1 , samples 17 and $21 \mathrm{EJ}$} \\
\hline Harmonic & $\begin{array}{c}\text { F-value } \\
\text { for Levine's test }\end{array}$ & $\begin{array}{l}\text { Tail probability } \\
\text { for Levine's test }\end{array}$ & & \\
\hline 2 & 14.1 & 0.49 & & NS \\
\hline 3 & 38.7 & 0.27 & & NS \\
\hline 4 & 51.3 & 0.47 & & NS \\
\hline 5 & 40.4 & 0.14 & & NS \\
\hline 6 & 52.3 & 0.12 & & NS \\
\hline 7 & 55.1 & 0.00 & HS & \\
\hline 8 & 59.1 & 0.02 & & \\
\hline 9 & 72.9 & 0.00 & HS & \\
\hline 10 & 73.1 & 0.02 & & \\
\hline 11 & 61.1 & 0.00 & HS & \\
\hline 12 & 52.1 & 0.00 & HS & \\
\hline 13 & 115.5 & 0.05 & & \\
\hline 14 & 87.6 & 0.01 & & \\
\hline 15 & 67.2 & 0.00 & HS & \\
\hline 16 & 68.8 & 0.00 & HS & \\
\hline 17 & 72.3 & 0.00 & HS & \\
\hline 18 & 74.0 & 0.00 & HS & \\
\hline 19 & 74.7 & 0.00 & HS & \\
\hline 20 & 81.8 & 0.00 & HS & \\
\hline 21 & 93.3 & 0.00 & HS & \\
\hline 22 & 59.1 & 0.00 & HS & \\
\hline 23 & 62.5 & 0.00 & HS & \\
\hline 24 & 62.6 & 0.00 & HS & \\
\hline
\end{tabular}

Abbreviations are: highly significant (HS), significant (S), nonsignificant (NS)

Sources

Quartz grain-shape is strongly related to the crystallization history, degree of structural deformation, character of microfracture sets in the protolith, as well as the type and amount of grain transport (Lu, 1992). Three major shape compositional fields are illustrated in Fig. 3. terpretado como representante de la aspereza o irregularidad de los granos. Para el factor 2 [muestras 10EJ (río) y 45EJ (plataforma interna)] los valores $F$ no son significativos estadísticamente entre las muestras miembros terminales $10 \mathrm{EJ}$ y $45 \mathrm{EJ}$ para los armónicos $2 \mathrm{al}$ 6; por tanto, con esta prueba no hay bases para interpretar que este factor es un componente de forma. Sin embargo, la forma univariada de la 
Table 3. Arithmetic means for amplitude values for harmonics two through six for samples $10 \mathrm{EJ}$ and $45 \mathrm{EJ}$, and values for Student-t test statistic between these two samples for each harmonic.

Tabla 3. Medias aritméticas de los valores de amplitud de los armónicos dos a seis, para las muestras $10 \mathrm{EJ}$ y $45 \mathrm{EJ}$, y valores de la prueba estadística t de Student entre estas dos muestras para cada armónico.

\begin{tabular}{cccccc}
\hline Statistics & \multicolumn{5}{c}{ Harmonics } \\
\cline { 2 - 6 } & Two & Three & Four & Five & Six \\
\hline Mean values & & & & & \\
10EJ & 10.9 & 7.2 & 4.8 & 3.6 & 2.8 \\
$45 \mathrm{EJ}$ & 7.16 & 4.8 & 3.2 & 2.4 & 1.7 \\
\hline Student's t-statistic & & & & & \\
10EJ versus 45EJ & $58.14^{*}$ & $35.7^{*}$ & $32.6^{*}$ & $23.85^{*}$ & $25^{*}$ \\
\hline
\end{tabular}

* Statistically significant at $1 \%$ level

Field 1 shows a group of river samples (samples $31,32,10 \mathrm{EJ}, 15 \mathrm{EJ}, 21 \mathrm{EJ})$. Field 2 shows a mixture of river (samples 9, 18, 24, 1EJ, 30EJ), beach $(11,19,25,2 \mathrm{~T}, 4 \mathrm{~B}, 5 \mathrm{~B}, 6 \mathrm{EJ})$ and dune $(35,41,19 \mathrm{EJ})$ samples, and field 3 shows samples from the inner continental shelf $(14,17$, $39 \mathrm{EJ}, 45 \mathrm{EJ}, 51 \mathrm{EJ}, 57 \mathrm{EJ})$, beaches $(20,21,29$, $39,49,1 \mathrm{~T}, 3 \mathrm{~T}, 4 \mathrm{~T}, 5 \mathrm{~T}, 13 \mathrm{EJ}, 2 \mathrm{M}, 3 \mathrm{M}, 4 \mathrm{M}, 1 \mathrm{~B}$, $2 \mathrm{~B}, 3 \mathrm{~B})$ and dunes $(5 \mathrm{EJ}, 14 \mathrm{EJ})$. Each group of samples can be related to a common source. Most of the river samples from field 1 are underlain by Miocene sandstone, which suggests that this rock may be an important source for local river sand. A second possible source is upper Tertiary conglomerate, which underlies sample 21EJ. This occurrence may suggest that the quartz grain-shape composition of this sample is the result of fracturing of quartz by cobbles and pebbles during transport of the conglomeratic sediment. A third probable source, which is located near the local river mouths, is beach and/or eolian sand. This source is suggested by the distribution of dune samples 5EJ, 14EJ and 19EJ (Fig. 3), which are located near the river mouths. The source of beach and eolian sand probably is from the conglomerate, and the resultant shape composition is caused by either selective entrainment, selective deposition and/or abrasion.

From the distribution in the factor plot of shelf samples 17 in Fig. 3, 39EJ, 51EJ and 57EJ, strata with a grain-shape composition similar to that of shelf sample $45 \mathrm{EJ}$ (the end- prueba Hotelling $\mathrm{T}^{2}$ fue usada para evaluar diferencias en medias de muestras para cada uno de los armónicos más pequeños. Los resultados de esta prueba se muestran en la tabla 3, la cual expone que hay diferencias estadísticas significativas para las medias de cada uno de los armónicos 2 al 6 de las muestras miembros terminales del factor 2 . Por tanto, el factor 2 puede ser interpretado como una medida de la forma del grano (aspereza). En tanto que las diferencias más grandes en las muestras miembros terminales están asociadas con el armónico 2 (tabla 3), este factor representa principalmente una medida de alargamiento de los granos.

Agrupaciones de forma de grano

Tres grupos principales de composición de forma están ilustrados en la Fig. 3. El grupo 1 representa formas de grano con valores altos de alargamiento y aspereza (irregularidad), caracterizados por muestras de río; el grupo 2 representa formas de grano con valores intermedios de alargamiento y valores de bajos a grandes de aspereza, que constituyen una mezcla de ambientes de rín, dunas y playas; y el grupo 3 representa formas de granos con valores bajos de alargamiento y aspereza, que son típicos en muestras de la plataforma continental interna. Las muestras miembros terminales provenientes de ríos (10EJ y 21EJ) están incluidas en el grupo 1 , y las de plataforma ( 17 y $45 E J)$ en el grupo 3 . 
member sample) seem to be the source for most of the shelf and beach samples. Sample 45EJ contains the most distinctive grain-shape composition. The beach samples are mixtures of shelf and fluvial sand, mostly derived from conglomeratic strata (Fig. 3).

\section{Creciente Island grain shape}

Most of the beach and core samples from Creciente Island are grouped in the beach-shelf field 3. The shape composition of the samples in this field is similar to the shelf samples, which suggests that they have a common source. The distribution of Creciente Island samples in the bivariate plot (Fig. 3) suggests that the resulting shape composition is probably due to the abrasion of shelf sand during the Holocene transgression, which reduced the original grain roughness of older fluvial sand, which was mixed with modern river sand derived from associated sandstone and conglomerate.

Along the south coast of Creciente Island, the shape composition of beach samples shows that the amount of shelf sand decreases from west to east along the island, and the amount of river sand increases in the same direction. It suggests that the amount of shelf sand has been diminished due to the dilution of shelf sand with modern river, beach and eolian sand to the east.

Vibracore samples from Creciente Island (Fig. 3) show that at the base of the east point core $(2: 02 \mathrm{~m})$, the sand was derived mostly from the shelf. Upward from the core base, the shelf sand has been diluted by mixing with modern river sand. The core base of the inner beach $(3.15 \mathrm{~m})$ shows mixed river and shelf sources, but is mostly shelf sand. Toward the top of this core, modern river-derived sand becomes dominant. At the base of the outer beach core $(2.18 \mathrm{~m})$, beach, eolian and shelf-derived sand is mixed, and the amount of shelf-derived sand increases toward the top.

The variation in grain-shape within the observed vibracores from Creciente Island reflects alternating periods of inner shelf- and river-dominant sedimentation. The inner coast and east point of Creciente Island show shelf sources to be dominant during deposition of the basal parts of these strata, whereas fluvial sedi-
Fuentes de abastecimiento

La forma de los granos de cuarzo está muy relacionada con el grado de deformación estructural, el carácter del conjunto de fracturas de la roca madre, así como con el carácter y cantidad de transporte de los granos ( $\mathrm{Lu}, 1992)$. Tres grupos principales de composición de forma están ilustrados en la Fig. 3. El grupo 1 incluye muestras de río (muestras 31,32 , 10EJ y $15 \mathrm{EJ}$ ). El grupo 2 muestra una mezcla de río (muestras $9,18,24,1 \mathrm{EJ}, 30 \mathrm{EJ})$, playa $(11,19,252 \mathrm{~T}, 4 \mathrm{~B}$, $5 \mathrm{~B}, 6 \mathrm{EJ})$ y dunas $(35,41,19 \mathrm{EJ})$, y el grupo 3 incluye muestras de la plataforma continental interna $(14,17,39 \mathrm{EJ}, 45 \mathrm{EJ}, 51 \mathrm{EJ}, 57 \mathrm{EJ})$, playa $(20,21,29,39,49,1 \mathrm{~T}, 3 \mathrm{~T}, 4 \mathrm{~T}, 5 \mathrm{~T}, 13 \mathrm{EJ}, 2 \mathrm{M}$, $3 \mathrm{M}, 4 \mathrm{M}, 1 \mathrm{~B}, 2 \mathrm{~B}, 3 \mathrm{~B}$ ) y dunas (5EJ, 14EJ). Cada grupo de muestras puede relacionarse con una fuente de abastecimiento común. La mayoría de las muestras de río del grupo 1 yacen sobre areniscas del Mioceno, lo cual sugiere que estas rocas pueden ser una fuente de abastecimiento importante de arena para los ríos locales. Una posible segunda fuente es el conglomerado del Terciario superior, que subyace la muestra de río 21EJ. Esta presencia puede sugerir que la composición de forma de los granos de cuarzo en el conglomerado es el resultado del fracturamiento de cuarzo por medio de gravas y gránulos durante su depositación. Una tercera fuente posible de abastecimiento, localizada cerca de la boca de los ríos locales, es arena de playas y/o dunas. Esto se infiere por la distribución, en el diagrama bivariado, de muestras de playa 11 y 19 , y de dunas $5 \mathrm{EJ}, 14 \mathrm{EJ}$ y $19 \mathrm{EJ}$ (Fig. 3), las cuales se localizan en la boca de los ríos locales. Las fuentes de arena de playa y duna probablemente provienen del conglomerado, y la composición de forma resultante es causada ya sea por entrada selectiva, depositación selectiva y/o abrasión.

A partir de la distribución de las muestras de plataforma $17,39 \mathrm{EJ}, 45 \mathrm{EJ}, 51 \mathrm{EJ}$ y $57 \mathrm{EJ}$ en el diagrama de factores (Fig. 3), estratos con una composición de forma de grano similar a la de la muestra 45EJ (muestra miembro terminal) parecen ser la fuente de abastecimiento para la mayoría de las muestras de plataforma y playa. La muestra $45 \mathrm{EJ}$ contiene la composición de forma de grano más distintiva. Las muestras de 
ment is dominant in the upper parts of these cores. The vibracore collected along the outer coast shows just the opposite trend. Although the available information does not permit a demonstrable cause or causes for the observed alternation in the dominance of inner shelf versus fluvial dominance, these alternations may reflect major storms which deliver pulses of inner shelf sand to the foreshore and/or intense rainfall which would increase fluvial sediment discharge to the shoreline, which then may be transported alongshore as a shape compositional bulge (Osborne and Yeh, 1991). Such a bulge would serve to dilute or bury shelf-derived sediment present along the foreshore.

From the shape composition of subsurface samples at Creciente Island, it can be inferred that for deeper levels of the recovered cores, the sand has been supplied principally from the inner continental shelf. Toward the tops of cores the shelf sand has been diluted by mixing with river-derived sand and modified by additional abrasion. The sand in the north, south and east points of Creciente Island probably experienced different sedimentologic histories, because this part of the island consists of a series of beach ridges.

It is clear from these results that the beaches at Creciente Island have two principal sand sources: the inner continental shelf, which includes water depths as much as $20 \mathrm{~m}$, and local rivers.

\section{Discriminate function analysis (DFA)}

Discriminate function analysis was employed as an appropriate multivariate statistical procedure to estimate the percentage of each beach sample derived from various potential sand sources. This analysis is one of the most powerful statistical procedures available to assign or partition samples into previously defined populations (Osborne and Yeh, 1991). Inasmuch as each potential source contains some grain-shape components common with those from other sources, standardized shape data must be recast to reflect the grain-shape unique to each potential source. After recasting, all resultant end-member sets must be stochastically distinct (Osborne and Yeh, 1992). playa son una mezcla de arena de plataforma y arena fluvial, principalmente derivada del estrato de conglomerado (Fig. 3).

\section{Forma de los granos en isla Creciente}

La mayoria de las muestras de playa y núcleo de isla Creciente están agrupadas en el grupo 3 , de playa de plataforma. La composición de forma de estas muestras es similar a las de plataforma, lo cual sugiere que tienen un origen común. La distribución de muestras de la isla en el diagrama bivariado (Fig. 3) sugiere que la composición de forma resultante se debe probablemente a la abrasión de la arena de plataforma durante la transgresión del Holoceno, la cual redujo la aspereza original del grano de la arena fluvial más antigua, que se mezcló con arena moderna de río, derivada de arenisca y conglomerado.

A lo largo de la costa sur de isla Creciente, la composición de forma de muestras de playa indica que la cantidad de material de la plataforma disminuye de la punta oeste hacia la punta este de la isla, y en la misma dirección aumenta el material de río. Esto sugiere que la cantidad de la arena de plataforma ha sido disminuida por la dilución de arena de plataforma con arena moderna de río, playa y arena eólica hacia el este de la isla.

Las muestras de núcleo de la punta este de isla Creciente (Fig. 3) señalan que en la base del punto este del núcleo $(2.02 \mathrm{~m})$ la arena fue principalmente derivada de la plataforma. De la base hacia la superficie del núcleo, la arena de plataforma ha sido diluida por la mezcla con la fuente de río moderno. La base del núcleo de la playa interna de la isla $(3.15 \mathrm{~m})$ muestra una mezcla de fuentes de río y plataforma con predominio de plataforma. Hacia la superficie del núcleo, la arena derivada de río moderno se hace dominante. Las muestras de núcleo de la playa externa de la isla muestran en la base del núcleo $(2.18 \mathrm{~m})$ una mezcla de arena derivada de playa, duna y plataforma, y la cantidad de arena derivada de la plataforma se incrementa hacia la superficie.

La variación de forma de grano dentro de los núcleos observados en isla Creciente reflejan periodos alternados de sedimentación domi- 
The results from DF $A$ are shown in table 4, which lists the mean percentages of sand derived from rivers (10EJ and 21EJ) and inner shelf (17 and 45EJ) for each sample. Table 4 shows that most of the samples contain higher percentages of the shelf end-members than the river end-members. The addition of the percentages from both end-members for each source shows that the beach samples from Creciente Island contain an average of approximately $52 \%$ inner continental shelf sand and about $48 \%$ river sand.

\section{DISCUSSION}

Shepard (1973) recognized the likely importance of the inner continental shelf as a source for littoral sand when he stated: "The direct source of almost all beach sand is the shallow sea floor, although previously the bulk of the shelf sand was carried into the ocean by runoff from the land... Beaches may also receive their supply from sands that were deposited on the continental shield during Pleistocene stages of low sea level when the shelves were largely dry land. Hence, here the terrestrial sources may be remote in time".

Along the low-gradient Atlantic and Gulf coasts, McMaster (1954, New Jersey), van Andel and Poole (1960, Texas Gulf coast), Seville (1960, Long Island), Curray (1960, northwest Gulf of Mexico), Giles and Pilkey (1965, southeastern United States) and Pierce (1968, Cape Hatteras) all concluded that much of the beach sand was derived from the erosion of older strata associated with the adjacent continental shelves. Along the higher-gradient $\mathrm{Pa}-$ cific coast, Trask (1952, Santa Barbara), Bowen and Inman (1966, Sebastián Vizcaíno Bay), Inman et al. (1966, Point Arguello), Clemens and Komar (1988, Cape Blanco), and Osborne and Yeh (1991, Oceanside) all have either suggested or documented net onshore sand transport from the shelf to the adjacent littoral zone. For the most part, these studies have been qualitative; however, Pierce (1968) estimated that about $42 \%$ of the annual sand input along a $100-\mathrm{km}$ coastal reach from Hatteras Inlet to Cape Lookout was derived from the adjacent shelf. Osborne and Yeh (1991) report that an nante de plataforma interna y de río. La costa interna y punta este de isla Creciente muestran el dominio de las fuentes de plataforma durante la acumulación de las partes basales de estos estratos, mientras que el sedimento fluvial es el dominante en las partes superiores de estos núcleos. Los núcleos obtenidos a lo largo de la costa exterior presentan justo la tendencia opuesta. Aunque la información disponible no permite demostrar una causa o causas de esta alternancia del dominio de plataforma interna contra el dominio fluvial, es posible que las alternancias reflejen grandes tormentas que dejaron pulsos de arena de la plataforma interna en la zona intermareal $y / o$ intensas lluvias que aumentaron la descarga de sedimento fluvial en la línea de costa, el cual puede haber sido transportado entonces, a lo largo de la costa, como un volumen composicional de forma (Osborne y Yeh, 1991). Un volumen así hubiera servido para diluir o enterrar el sedimento presente derivado de la plataforma a lo largo de la zona intermareal.

A partir de la composición de forma de las muestras de núcleo de isla Creciente, puede inferirse que en los niveles más profundos de la isla la arena ha sido abastecida en su mayor parte por la plataforma. Hacia la superficie, la fuente de la plataforma ha sido diluida principalmente por mezcla con arena derivada de río (conglomerado) y modificada por abrasión adicional. La depositación de arena en las playas, interna, externa y en las puntas de isla Creciente representa, probablemente, historias diferentes debido a que esta parte de la isla está formada por una serie de cordones de playa.

De acuerdo con los resultados, la isla Creciente tiene dos fuentes principales de abastecimiento de arena: la plataforma continental interna, incluyendo profundidades de hasta aproximadamente $20 \mathrm{~m}$, y los ríos locales.

\section{Análisis de función discriminante (AFD)}

El análisis de función discriminante se empleó como procedimiento estadístico multivariado apropiado para estimar los porcentajes de arena de playa derivados de varias fuentes potenciales de abastecimiento de arena. Este análisis es uno de los procedimientos estadísticos disponibles más útiles para designar o divi- 
average of $36 \%$ of the foreshore sand in the Oceanside area is shelf-derived. The Clemens and Komar (1988) model may be considered one spectral end-member where no new shelf sand is currently transported to the beach, whereas Pierce's model suggests more continuous additions of shelf sand in response to longperiod waves and/or storm-generated currents.

The shelf source identified at Creciente Island probably represents a lag deposit enriched in smoother and more spherical grains due to the selective transport of more rough and elongate grains during a recent but as yet undefined time period. Similar shelf deposits have been discovered offshore of Oceanside (Osborne and Cho, 1989) and offshore of Dockweiler Beach at Los Angeles (Lu, 1992). Osborne et al. (in press) discuss the continental shelf as a source for beach sand along the southern California bight.

\section{CONCLUSIONS}

The shape composition of detrital quartz grains in samples from Creciente Island and vicinity was examined using Fourier grain-shape analysis and associated statistical methods, including factor analysis, analysis of variance, and significance testing (F-test). Analysis of resultant data shows the following:

1. There are two distinctive grain-shape populations present. The first is characterized by relatively high values for both asperity and elongation mainly (roughness), and the second by relatively low values for both asperity and elongation. These grain-shape populations are represented by river $(10 \mathrm{EJ}, 21 \mathrm{EJ})$ and inner continental shelf $(17,45 \mathrm{EJ})$ samples, respectively.

2. The most important shape characteristic of quartz grains is asperity or roughness, which explains $61 \%$ of the total sample variance.

3. Surface and subsurface sand samples from Creciente Island are composed mostly of sand derived from the inner shelf $(52 \%)$, which has been mixed with fluvial sand $(48 \%)$, mostly from La Presa and San Venancio basin drainages. The resultant grain-shape composition is the product of abrasion and selective transport before and after primary sand deposition. dir muestras entre poblaciones previamente definidas (Osborne y Yeh, 1991). Debido a que cada fuente potencial tiene algunos componentes comunes a aquéllos de las otras formas de grano, los datos iniciales estandarizados de forma se recalcularon para que los valores reflejaran sólo una única forma de grano para cada fuente de abastecimiento potencial. Después de recalcular los valores, todos los juegos de muestras miembros terminales resultantes deben ser estocásticamente distintas (Osborne y Yeh, 1992).

Los resultados del AFD se presentan en la tabla 4, donde se listan los porcentajes medios de arena derivada de ríos (10EJ y $21 \mathrm{EJ}$ ) y plataforma interna ( 17 y $45 \mathrm{EJ})$ para cada muestra. La tabla indica que la mayoría de las muestras contienen porcentajes más altos de las muestras miembros terminales de plataforma que de las muestras miembros terminales de ambiente de río. La suma de los porcentajes de ambas muestras miembros terminales de cada fuente indica que las muestras de playa de la isla Creciente contienen un promedio aproximado de $52 \%$ de arena abastecida de la plataforma interna y uno de $48 \%$ de arena de río.

\section{DISCUSION}

Shepard (1973) reconoció la importancia de la plataforma continental como fuente de abastecimiento de arena litoral, cuando afirmó que: "La fuente directa de casi toda la arena de playa es el fondo de mar somero, aun si el volumen de la arena de plataforma ha sido llevado previamente hacia el océano por escorrentía terrestre... Las playas pueden también recibir ese abastecimiento, de arenas que fueron depositadas sobre el escudo continental durante el Pleistoceno, cuando el nivel del mar era bajo y las plataformas eran porciones de tierras extremadamente secas. Aquí, por tanto, las fuentes terrestres pueden ser remotas en tiempo."

De acuerdo con el gradiente bajo a lo largo de las costas del Golfo y del Atlántico, McMaster (1954, New Jersey), van Andel y Poole (1960, costa del golfo de Texas), Saville (1960, Long Island), Curray (1960, noroeste del golfo de México), Giles y Pilkey (1965, sureste de Estados Unidos) y Pierce (1968, cabo Hatter- 
Table 4. Results of discriminate function analysis using recast Fourier grain-shape data.

Tabla 4. Resultados del análisis de función discriminante, usando datos recalculados con Fourier para forma de grano.

\begin{tabular}{|c|c|c|c|c|c|c|c|}
\hline & & & & & & & \\
\hline & & & Rivers & & & Shelf & \\
\hline End me & mbers & $10 \mathrm{EJ}$ & $21 \mathrm{EJ}$ & Total & 17.0 & 45EJ & Total \\
\hline Dune & $14 \mathrm{EJ}$ & 14.8 & 37.2 & 52.0 & 27.6 & 20.5 & 48.0 \\
\hline & $19 \mathrm{EJ}$ & 14.8 & 33.2 & 48.0 & 29.8 & 22.2 & 52.0 \\
\hline & $5 \mathrm{EJ}$ & 15.2 & 33.2 & 48.3 & 30.8 & 20.9 & 51.7 \\
\hline Shelf & 14 & 15.6 & 30.2 & 45.7 & 33.4 & 20.9 & 54.3 \\
\hline & $39 \mathrm{EJ}$ & 13.6 & 34.8 & 48.4 & 28.2 & 23.4 & 51.6 \\
\hline & 5IEJ & 14.0 & 33.6 & 47.6 & 28.6 & 23.9 & 52.4 \\
\hline & $57 \mathrm{EJ}$ & 13.5 & 35.5 & 49.0 & 27.2 & 23.9 & 51.0 \\
\hline Beach & 11 & 14.2 & 34.0 & 48.2 & 28.3 & 23.5 & 51.8 \\
\hline & 19 & 14.2 & 33.7 & 47.8 & 28.3 & 23.9 & 52.2 \\
\hline & 20 & 14.2 & 40.0 & 54.2 & 25.8 & 20.0 & 45.8 \\
\hline & 21 & 14.1 & 32.5 & 46.7 & 29.8 & 23.5 & 53.4 \\
\hline & 25 & 13.5 & 33.6 & 47.0 & 27.4 & 25.6 & 53.0 \\
\hline & 29 & 14.4 & 34.0 & 48.3 & 29.1 & 22.6 & 51.7 \\
\hline & 3 & 14.9 & 36.2 & 51.1 & 28.6 & 20.3 & 48.9 \\
\hline & 35 & 13.4 & 35.3 & 48.7 & 26.5 & 24.9 & 51.3 \\
\hline & 39 & 14.5 & 35.2 & 49.7 & 28.5 & 21.9 & 50.3 \\
\hline & 41 & 13.9 & 33.7 & 47.6 & 27.7 & 24.7 & 52.4 \\
\hline & 46 & 11.5 & 31.8 & 43.2 & 26.8 & 30.0 & 56.8 \\
\hline & 49 & 14.6 & 32.8 & 47.4 & 30.4 & 22.2 & 52.6 \\
\hline & 7 & 12.9 & 35.0 & 47.9 & 26.6 & 25.6 & 52.1 \\
\hline & $6 \mathrm{EJ}$ & 13.7 & 32.5 & 46.2 & 28.4 & 25.4 & 53.8 \\
\hline & $13 \mathrm{EJ}$ & 14.8 & 35.4 & 50.2 & 29.4 & 20.5 & 49.8 \\
\hline
\end{tabular}

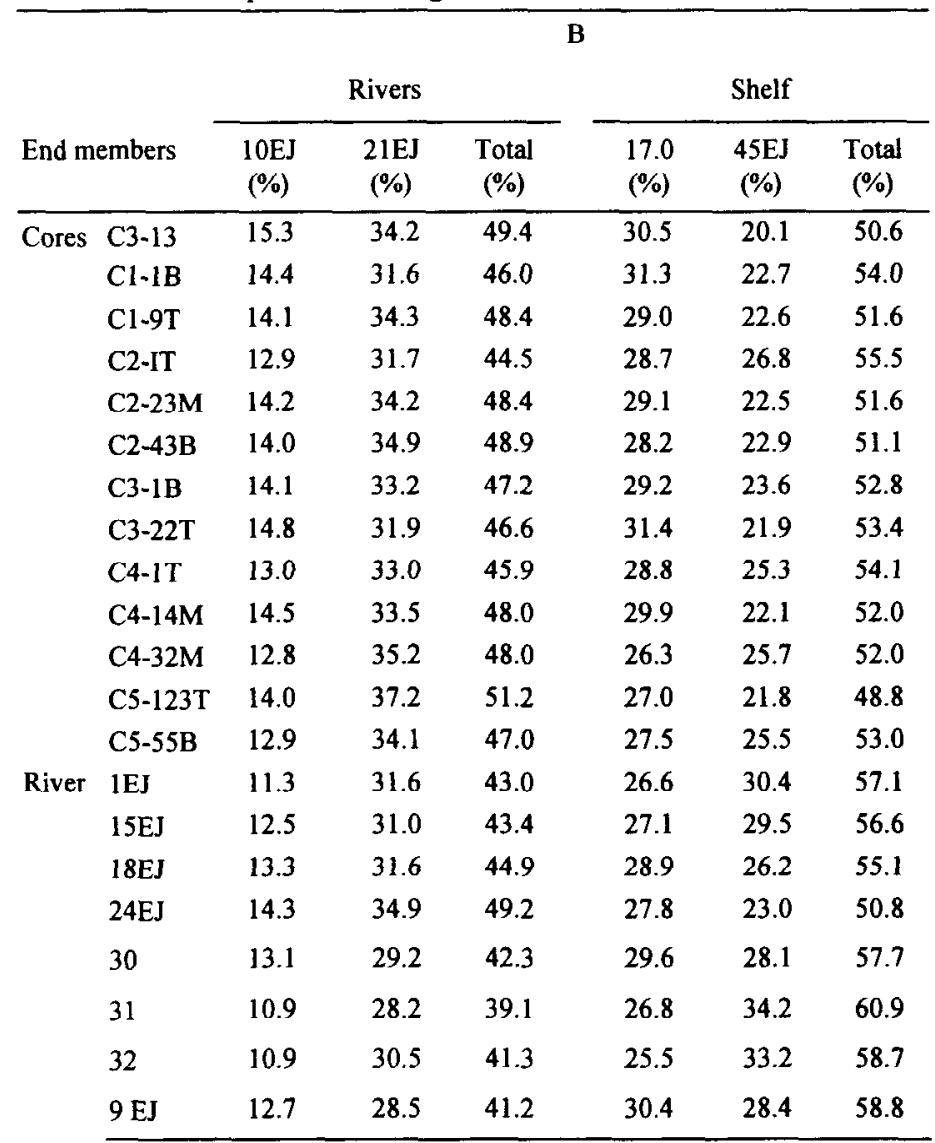


4. Inner shelf sand is dominant in the lower part of cores from Creciente Island (-2 to $-3 \mathrm{~m})$; however, shelf sand has been diluted by mixing with river sand in higher parts of these cores.

5. Alternating periods of inner shelf- and river-dominant sedimentation within the vibracores at Creciente Island may reflect major storms which deliver pulses of inner shelf sand to the foreshore and/or intense rainfall which would increase fluvial sediment discharge to the shoreline.

6. From west to east along Creciente Island, the shelf-derived sand has been diluted by mixing with fluvial sand.

7. The shape composition of river samples near the river mouths and beach samples along the east coast of Las Almejas Lagoon is a mixture of shelf and river-derived sand, which has been somewhat modified by abrasion and selective transport.

8. Most of the eolian sand (dunes) samples were derived from fluvial sources; however, some are a mixture of river- and shelf-derived sand. The resultant grain-shape composition was modified by the selective transport and or selective deposition of more rough and elongate grains.

9. From the preceding discussion concerning barrier island formation, sea level changes, and the results of Fourier grain-shape analysis for samples from Creciente Island and vicinity, it is concluded that Tertiary sandstone and conglomerate from the study area were exposed and eroded during the Wisconsin glaciation which terminated about 18,000 years B.P. $(-130 \mathrm{~m}$ $\mathrm{msl}$ ). The sand derived from these strata was deposited by rivers on the enlarged continental shelf present at that time. Following the Wisconsin glacial maximum, a global transgression occurred from 18,000 to 5,000 years B.P., and the sand derived from the Tertiary sandstone and conglomerate units was exposed to marine waves and currents to form a transgressive blanket sand. When the Holocene transgression slowed about 5,000 years B.P., Creciente barrier island was formed. The strata comprising Creciente Island are composed mostly of reworked inner shelf sand with admixtures of fluvial sand from La Presa and San Venancio basin drainages. as) concluyeron que mucha de la arena de la playa se derivó de la erosión de estratos más antiguos asociados con las plataformas continentales adyacentes. De acuerdo con el gradiente más alto a lo largo de la costa del Pacífico, Trask (1952, Santa Barbara), Bowen e Inman (1966, bahía de San Sebastian Vizcaino), Inman et al. (1966, punta Arguello), Clemens y Komar (1988, cabo Blanco) y Osborne y Yeh (1991, zona oceánica) han sugerido o documentado transporte neto de arena de la plataforma hacia la zona litoral adyacente. En su mayoría, estos estudios han sido cualitativos; sin embargo, Pierce (1968) estimó que cerca del $42 \%$ de la descarga anual de arena a lo largo de $100 \mathrm{~km}$ de costa, de boca Hatteras a cabo Lookout, se derivó de la plataforma adyacente. Osborne y Yeh (1991) informan que un promedio de $36 \%$ de arena de la zona intermareal de la playa en el área de Oceanside se deriva la plataforma. El modelo de Clemens y Komar (1988) puede ser considerado como un miembro terminal espectral donde normalmente no se transporta arena nueva a la playa, mientras que el modelo de Pierce sugiere más una continua adición de arena de plataforma en respuesta al oleaje de periodo grande $y / o$ a corrientes generadas por tormentas.

La fuente de plataforma identificada en isla Creciente probablemente representa un depósito remanente enriquecido en granos más esféricos y lisos debido al transporte selectivo de granos más alargados y ásperos durante un periodo de tiempo reciente, aún indefinido. Depósitos de plataforma similares han sido descubiertos frente a la costa de Oceanside (Osborne y Cho, 1989) y frente a la playa Dockweiler en Los Angeles (Lu, 1992). Osborne et al. (en prensa) discuten la contribución de arena de plataforma continental como fuente de abastecimiento de arena de playa a lo largo de la costa del sur de California.

\section{CONCLUSIONES}

La composición de forma de los granos de cuarzo detrítico en muestras de isla Creciente y alrededores se examinó usando el análisis de Fourier para forma de grano y los métodos estadísticos asociados, incluyendo análisis de fac- 


\section{ACKNOWLEDGEMENTS}

We are grateful to the University of Southern California and Universidad Autónoma de Baja California Sur for logistic support. Jinyou Liu and Rory Robinson collaborated in the stastical analysis.

\section{REFERENCES}

Bowen, A.J. and Inman, D.L. (1966). Budget of littoral sands in the vicinity of Point Arguello. Coastal Engineering Research Center, U.S. Army Corps of Engineers, Technical Memorandum No. 19, 41 pp.

Broadhead, S.D. (1988). Fourier grain-shape analysis of the sources and littoral transport of sand, San Elijo Lagoon to Point La Jolla. Unpublished M.S. thesis, University of Southern California, Los Angeles, $235 \mathrm{pp}$.

Carver, R.E. (1971). Procedures in Sedimentary Petrology. Wiley-Interscience, Inc., New York, 653 pp.

Clark, R.A. and Osborne, R.H. (1982). Contribution of Salinas River sand to the beaches of Monterey Bay, California, during the 1978 flood period: Fourier grainshape analysis. Journal of Sedimentary Petrology, 52: 807-822.

Clemens, K.E. and Komar, P.D. (1988). Oregon beach-sand composition produced by mixing of sediments under a transgressing sea. Journal of Sedimentary Petrology, 59: 519-529.

Curray, J.R. (1960). Sediments and history of Holocene Transgression, continental shelf, northwest Gulf of Mexico. In: F.P. Shepard, F.B. Phleger and Tj.H. van Andel, (eds.), Recent Sediments, Northwest Gulf of Mexico. American Association of Petroleum Geologists, Tulsa, Oklahoma, pp. 221-266.

Davis, J.C. (1986). Statistics and Data Analysis in Geology. John Wiley, New York, 2nd ed., $646 \mathrm{pp}$.

Dixon, W.J. (1990). BMDP Statistical Software Manual, Vol. 1, 2. University of California Press, Berkeley, 1385 pp. tores, análisis de varianza y prueba de significación (prueba F). El análisis de los datos obtenidos muestra lo siguiente:

1. Hay dos poblaciones distintivas de forma de grano presentes. La primera se caracteriza, por valores relativamente altos de aspereza $y$ alargamiento, y la segunda, por valores relativamente bajos tanto de aspereza como de alargamiento. Estas poblaciones de forma de grano están representadas por muestras de ríos (10EJ, $21 \mathrm{EJ})$ y de plataforma continental interna (17, $45 \mathrm{EJ}$ ), respectivamente,

2. La característica de forma más importante en los granos de cuarzo es la aspereza, la cual explica el $61 \%$ de la varianza total en la muestra,

3. Las muestras superficiales y subsupert1ciales de isla Creciente están compuestas principalmente de arena derivada de la plataforma continental (52\%), la cual se ha mezclado con arena fluvial (48\%), principalmente de las cuencas de drenaje San Venancio y La Presa. La composición de forma de grano resultante es producto de la abrasión y transporte selectivo antes y después de la depositación de arena primaria,

4. La arena de la plataforma continental interna es dominante en la base de los núcleos obtenidos en isla Creciente ( -2 a $-3 \mathrm{~m})$; sin embargo, la arena de plataforma se ha diluido por la mezcla con arena de río, en las partes más altas de estos núcleos,

5. Los periodos alternados de dominio de sedimentación de plataforma interna y de río en los núcleos de la isla Creciente pueden reflejar grandes tormentas que intermitentemente abastecieron de arena de la plataforma interna al espacio intermareal de la playa y/o lluvia intensa, que pudo incrementar la descarga de sedimento fluvial en la orilla de la costa.

6. A lo largo de isla Creciente, de oeste a este, la arena derivada de la plataforma ha sido diluida al mezclarse con arena fluvial.

7. La composición de forma de grano de las muestras de río cercanas a la boca de los ríos y las muestras de playa a lo largo de la costa este de laguna Las Almejas es una mezcla de arena derivada de ríos y plataforma, que ha sido de alguna manera modificada por la abrasión y el transporte selectivo. 
Ehrlich, R. and Weinberg, B. (1970). An exact method for characterization of grain shape. Journal of Sedimentary Petrology, 40: 205-212.

Ehrlich, R., Brown, P.J., Yarus, J.M. and Przygocki, R.S. (1980). The origin of shape frequency distribution and the relationship between size and shape. Journal of Sedimentary Petrology, 50: 475-484.

Giles, R.T. and Pilkey, O.H. (1965). Atlantic beach and dune sediments of the southern United States. Journal of Sedimentary Petrology, 35: 900-910.

Inman, D.L., Ewing, G.C. and Corliss, J.B. (1966). Coastal sand dunes of Guerrero Negro, Baja California. Geological Society of America Bulletin, 77: 787-802.

Lankford, R.R. (1977). Coastal lagoons of Mexico: their origin and classification. In: M. Wiley (ed.), Estuarine Processes, 2. Academic Press, New York, 428 pp.

Liu, J. (1993). The origin of quartz-shape facies and their variation as functions of grain size and transport distance, San Diego County, California. Unpublished Ph.D. dissertation, University of Southern California, Los Angeles, $206 \mathrm{pp}$.

Lu, Y. (1992). Fourier grain-shape analysis of beach sand samples and associated sedimentary processes, Dockweiler and El Segundo Beaches, Santa Monica Bay, southern California. Unpublished Ph.D. dissertation, University of Southern California, Los Angeles, $200 \mathrm{pp}$.

McMaster, R.L. (1954). Petrography and genesis of the New Jersey beach sands. New Jersey State Department of Conservation Series, Bulletin 63: 239.

Murillo, J.M. (1993). Characteristics and sources of the Creciente Barrier Island sediments within Margarita LagoonalComplex, Baja California Sur, Mexico. Unpublished M.S. thesis, University of Southern California, Los Angeles, 378 $\mathrm{pp}$.

Osborne, R.H. and Cho, K.H. (1989). Sedimentology of a composite inner-shelf sand body resulting from the resuspension of nearshore sediment by episodic, stormgenerated currents. Proceedings Volume,
8. La mayoría de las muestras de arena eólica (dunas) se derivaron de una fuente fluvial; sin embargo, algunas tienen mezcla de arena derivada de plataforma y de río. La composición de forma resultante fue modificada por el transporte selectivo y/o por la depositación selectiva de granos más alargados y ásperos.

9. A partir de la discusión anterior, que se refiere a la formación de las islas de barrera, cambios del nivel del mar, y los resultados del análisis de Fourier para forma de grano en muestras de isla Creciente $y$ alrededores, se concluye que las areniscas terciarias y conglomerados del área de estudio fueron expuestas y erosionadas durante la glaciación Wisconsiana, que terminó hace 18,000 años A.C. $(-130 \mathrm{~m} \mathrm{nmm})$. La arena derivada de estos estratos fue depositada por ríos sobre la extensa plataforma continental presente en ese tiempo. Siguiendo a la máxima glaciación Wisconsiana, una transgresión global ocurrió entre los 18,000 y 5,000 años A.C., y la arena derivada de las unidades de areniscas terciarias y conglomerados fue expuesta al oleaje marino y las corrientes, que formaron una sábana de arena transgresiva. Cuando la transgresión Holocena disminuyó, cerca de los 5,000 años A.C., se formó la isla de barrera Creciente. Los estratos que comprenden isla Creciente están compuestos principalmente de arena retrabajada de la plataforma interna, con una mezcla de arena fluvial de las cuencas de drenaje La Presa y San Venancio.

\section{AGRADECIMIENTOS}

Agradecemos, a la Universidad del Sur de California y a la Universidad Autónoma de Baja California Sur, el apoyo logístico; a Jinyou Liu y Rory Robinson, su colaboración en el análisis estadístico.

Traducido al espanol por los autores.

Coastal Zone '89, American Society of Civil Engineers, pp. 2210-2224.

Osborne, R.H. and Yeh, C.C. (1991). Fourier grain-shape analysis of coastal and inner continental shelf sand samples: Oceanside littoral cell, southern Orange and San 
Diego Counties, southern California. In: R.H. Osborne (ed.), From Shoreline to Abyss: Contributions in marine geology in honor of Francis Parker Shepard. SEPM Special Publication 46, pp. 51-66.

Osborne, R.H. and Yeh, C.C. (1992). Applicationes of Fourier grain-shape analysis in the search for more accurate sediment budgets, southern Orange and San Diego Counties, California. In: B.W. Pipkin and R.J. Proctor (eds.), Engineering Geology Practice in Southern California. Association of Engineering Goelogists, Special Publication No. 4, pp. 485-500.

Osborne, R.H., Cho, K.H., Compton, E.A. (1989) and Fogarty, T. (1988). Processes locations and rates of coastal cliff erosion from 1887 to 1947, Dana Point to the Mexican border. Los Angeles District, U.S. Army Corps of Engineers, Coast of California Storm and Tidal Waves Study, CCSTWS 88-8, 300 pp., 6 plates.

Osborne, R.H., Ahischwede, K.S., Broadhead, S.D., Cho, K.H., Compton, E.A. and Yeh, C.C. (1990). Fourier grain-shape and mineralogic analysis of coastal and inner shelf sand samples: Dana Point to the United States-Mexico border. Los Angeles District, U.S. Army Corps of Engineers, Coast of California Storm and Tidal Waves Study, CCSTWS 89-1, 116 pp.

Osborne, R.H., Bomer, E.J., III, Wang, Y.C. and Lu, Y. (1993). Application of a tumbler experiment using granodioritic grus to examine the character of quartz-grain fracture in high-gradient streams. In: M.J. Johnsson and A. Basu (eds.), Processes
Controlling the Composition of Clastic Sediments. Geological Society of America Special Paper 284, 26, pp. 211-324.

Osborne, R.H., Ahlschwede, K.A., Broadhead, S.D., Cho, K., Feffer, J.R, Lee, A.C., Liu, J., Magnusen, C., Murillo de Nava, J.M., Robinson, R.A., Yeh, C.C. and Lu, Y. The continental shelf: A source for naturallydelivered beach sand. Coastal Dynamic '94, American Society of Civil Engineers (in press).

Pierce, J.W. (1968). Sediment budget along a barrier island chain. Sedimentary Geology, 3: 5-16.

Saville, T. (1960). Sand transfer, beach control, and inlet improvements, Fire Island Inlet to Jones Beach, New York. Seventh Conference on Coastal Engineering, pp. 785-807.

Schwarcz, H.P. and Shane, K.C. (1969). Measurement of particle shape by Fourier analysis. Sedimentology, 13: 213-231.

Shepard, F.P. (1973). Submarine Geology. New York Harper \& Row, Publishers, 3rd ed., $517 \mathrm{pp}$.

Schultz, D. (1980). The effects of hydrofluoric acid on quartz grain shape Fourier grain shape analysis. Journal of Sedimentary Petrology, 50: 644-645.

Trask, P.D. (1952). Source of beach sand at Santa Barbara, California, as indicated by mineral grain studies. Beach Erosion Board, U.S. Army Corps of Engineers, Technical Memorandum No. 28, 24 pp.

Van Andel, Tj.H. and Poole, D.M. (1960). Sources of recent sediments in the northern Gulf of Mexico. Journal of Sedimentary Petrology, 30: 91-122. 